\title{
The Increase of Student Learning Interest through the Application of Recitation Methods Assisted by Cyber Counseling Media
}

\author{
Deliati $^{1}$, Gusman Lesmana ${ }^{2}$ \\ ${ }^{1,2}$ Muhammadiyah University of North Sumatra, Indonesia \\ deliati@umsu.ac.id
}

\begin{abstract}
Research data were analyzed through reflective studies in each cycle. The results of data analysis shows that in the first cycle there had been an increase in students learning interest with a success percentage of $38.10 \%$ compared with students learning interest before being given action in the first cycle (23.91\% of students were successful). However, in this cycle there are still some shortcomings because most students are not familiar with the learning conditions through the recitation method. The shortcomings in the first cycle are seen from the low level of students learning interest in the learning process with an average percentage of $67.26 \%$, lecturer activities $75.05 \%$, and the ability of students with an average score of 71.90 with a success percentage of 54,35\%. In the second cycle, student learning interest and the way lecturers teaching is run better. The activity of students and lecturers in learning has increased with a percentage score of $71.88 \%$ and $83.77 \%$, with a graduation rate of $58.70 \%$. Student mastery of the material also increased with an average score of $74.40 \%$. The implementation of the third cycle starts from the problem at the stage of action II. The average score of students' ability to mastery of the material obtained in action III is 85.83, with a graduation rate of $91.30 \%$. The average score of student activities in PBM is $78.80 \%$. Meanwhile, lecturers' activities in learning also improved well, with a percentage of $87.70 \%$.
\end{abstract}

Keywords : Learning interest; recitation methods; Cyber Counseling.

\section{Introduction}

The case experienced by researcher as a lecturer in counseling psychology when providing the learning process. According to Dalyono (2009) in an effort to achieve something needed interest, the size of interest greatly influences the results obtained. Interest is basically the acceptance of a relationship yourself with something outside yourself. The stronger or nearer the relationship, the greater the interest

According to Djaali (2006) the existence of a person's relationship with something outside of themselves, can lead to a sense of attraction, so that there is acceptance. For example students are tried to practice face-to-face with clients and know what services should be used in applying recitation methods to deal with troubled clients. This is in line with the statements of Prayitno and Erman Amti (2004: 105). Recitation methods is one way of delivering teaching designed for students to be eager to find and find out their own answers to assignments given by the teacher Syaiful Sagala, (2005). Moh. Surya (2006) explains that in line with the development of computer technology, the interaction between counselors and clients is not only done through face-to-face relationships but can also be done through virtual (virtual) relationships through the internet, in the form of cyber counseling. 


\section{Review of Literatures}

\section{a. Learning Interest}

According to Ahmadi (2009: 148) "Interest is the attitude of the soul of a person including the three functions of his soul (cognition, conation, and emotion), which is aimed at something and it related to the strong element of feeling. The success of learning can be achieved if the related elements can be implemented properly. The success of learning in increasing students learning interest by using learning media (Nurdin et al., 2011). The learning interest or encouragement to learn comes from a learning atmosphere that will provide motivation and freedom in exploring or analyzing learning experiences. According to Slameto (2010: 180) several indicators of learning interest are: feelings of pleasure, attraction, acceptance, and student involvement. Of the several definitions put forward regarding the learning interest indicators mentioned above, in this study using interest indicators were: Happy Feelings, Involvement, Interest, and Attention.

\section{b. Counseling Psychology}

In essence counseling psychology refers to scientific studies of psychological aspects involved in the counseling process, namely the psychological aspects of the counselor, the client and on the interaction between the counselor and the client (Mappiare, 2006)

\section{c. Recitation Learning Methods}

According to M. Basyirudin Usman, (2008) Recitation method is one method that is applied in involving students actively and with full sense of responsibility and awareness to do it, in order to support the smooth learning process. According to Syaiful Bahri Djamarah and Azwan Zain (2010), the method of presenting materials where the teacher gives certain assignments so that students carry out learning activities.

\section{d. Cyber Counseling Media}

According to Istiningsih (2012) counselors use information media as a tool in carrying out their duties, which is then known as cyber counseling services. Moh. Surya (2006) suggests that in line with the development of computer technology, the interaction between counselors and clients is not only done through face-to-face relationships but can also be done through virtual relationships through the internet in the form of "cyber counseling".

\section{e. The Steps of the Increase of Recitation Methods Assisted by Cyber Counseling Media}

Bahri Djamarah and Aswan Zain, (2010) put forward the things that need to be considered in the steps of implementing the recitation method, among others: Phase of presenting the task given to students should consider: Objectives to be achieved; The type of task is clear and precise so that the student understands what is assigned, according to the ability of the student.

\section{Research Methods}

The research data were analyzed by Miles and Huberman (2007) models, namely through three stages: (a) data reduction, (b) data presentation, and (c) conclusion / verification. 


\section{Results and Discussion}

\section{Description of Cycle I Results}

\section{a. Action Planning}

The planning was designed based on the results of the initial tests and observations, namely (a) making a scenario of learning Counseling Psychology in accordance with the Recitation Method assisted by Cyber Counseling that will be used in action, (b) making observation sheets to see the learning atmosphere, and Learning Interests of Student and Lecturer, and (c) designing evaluation tools to see an increase in student learning interest in Counseling Psychology learning.

\section{b. Implementation of Action}

This is caused by several factors, namely; (a) students have not been able to adapt to the study group so that learning tends to be individual, (b) some students do not understand group learning with the recitation method to overcome the above problems, the following efforts are carried out: (a) the lecturer provides students with group learning Recitation methods, and their benefits in learning, and (b) lecturers actively help groups that have not understood the steps in learning the Recitation method. (c) Some students are not ready to use Cyber counseling as a learning media to the fullest.

\section{c. Observation and Evaluation Stage}

The student learning interest is still relatively low with a percentage of Happy Feelings of $70.65 \%$, Involvement of $71.20 \%$, Interest of $65.76 \%$, and attention of $61.41 \%$. The highest is the aspect of Student Involvement, and the lowest is the aspect of Attention. From the overall, the average level of student learning interest in PBM in the first cycle was 67, 26. This can be seen from the average score of the observations of the activities of lecturers which is equal to $75.05 \%$. It can be concluded that the activities of lecturers in learning activities are still not sufficient. From the ideal score of 100, the average score only reached 71.90 , with details of the score of only 11 students from 46 students who obtained successful scores.

\section{d. Reflection Stage}

There are successes and failures that occur in the first cycle as follows: This can be seen from the average observation results of student activities in the teaching and learning process (PBM) with a percentage level of $67.26 \%$. Some students have not utilized the Cyber counseling application as a learning media to the fullest. Lecturers are still awkward or not accustomed to creating an active learning atmosphere using the media-assisted Recitation Method Cyber Counseling. The level of lecturer activity in learning is still relatively low with a percentage rate of $70.78 \%$. The level of mastery of students towards learning material is still relatively low. In other words, the level of student learning achievement is still not good, with an average score of the percentage of success reaching only $38.10 \%$.

\section{Description of Cycle II Results}

a. Planning Stage 
Preparation of learning plans in the second cycle is based on the results of reflection on the first cycle action. In this action improvisation or modification of the learning steps in the part that becomes an obstacle in the first action.

\section{b. Action Stage}

The researcher sees in general, the learning activities in the second cycle are the same as in the first cycle. The learning process begins with an explanation of the technique about 30 minutes, and deliver the learning material in outline. Then, each group was given 60 minutes to discuss the material in their respective groups.

\section{c. Observation and Evaluation Stage}

The average score of student activity between the first cycle, $67.26 \%$ and the second cycle II $71.88 \%$. It can be concluded that student learning interest experiences changes or improvements in the second cycle even though they occur significantly. The results of student observations on the activities of lecturers in teaching are classified as good, with an average score of $83.77 \%$, where the highest score is apperception with a score of $90.48 \%$. Meanwhile, the lowest score at the stage of explanation of the learning model of the recitation method is aided by Cyber counseling media, which is equal to $79.76 \%$. This shows that there is a significant improvement of lecturer activities in the teaching and learning process from the first cycle to the second cycle, with a comparison rate of $8,72 \%$. The second cycle is classified as good with an average score of 74.40, and a graduation percentage of 58.70\%. Student score distribution can be explained in detail as follows: scores of 45 and 50 are obtained by each 1 (one) student and the score of 55 is obtained by 5 students. Furthermore, scores of 60 and 65 were obtained by 6 students each. Then, the score of 70 is obtained by 10 students, 75 are 11 students, while the score of 80 is 6 students. From these data it can be concluded that student learning outcomes progress. In other words, student learning achievements experience a fairly good increase in cycle II.

\section{d. Reflection Stage}

In this case, it can be seen from the data from the observation of student activities increasing from $67.26 \%$ in the first cycle to $71.88 \%$ in the second cycle. Meanwhile, the score of student learning interest also increased with the success rate of $54.35 \%$ in the first cycle increasing to $58.70 \%$. The observation results of lecturer activities in PBM increased from $75.05 \%$ in the first cycle to $83.77 \%$ in the second cycle.

\section{Description of Cycle III Results}

\section{a. Planning Stage}

In the third cycle, action planning is a follow-up of problems or obstacles encountered in the implementation of the second cycle of action. Learning in the third action aims to increase students' interest in learning in order to achieve the specified indicators.

\section{b. Action Stage}

Then the next learning process is similar to the previous meeting but with different learning materials.

c. Observation and Evaluation Stage 
The development is very good with an average percentage of $78.80 \%$. From the four aspects of observation, the aspect of student involvement obtained the highest score of $81.25 \%$, while the lowest aspect was in the aspect of happy feeling with a score of $75.00 \%$. Increased student learning interest between the second and third cycles, both abilities individually and in groups. It can be seen from the average score of student interest between the second cycle, $71.88 \%$ and the third cycle, $78.80 \%$, with a difference in the comparison rate of $6.92 \%$. This number implies that student learning interest increases significantly from the previous cycle. The results of lecturer activity in the teaching and learning process are very good, with an average score percentage of $87.77 \%$. Thus, in this third cycle, lecturer activities experienced a very rapid increase in the teaching and learning process compared to the two percentage cycles of the previous cycle, the first cycle, $75.05 \%$ and $83.77 \%$ for the second cycle. Student mastery of learning material in the third cycle is getting better with an average score of 85.83 . The detailed description of the acquisition of these scores is 65 and 70 obtained by 4 students each, 10 students with a score of 75,16 students with a score of 80,9 students with a score of 85 , and 3 students with a score of 90 . The overall mastery of the material is $91.30 \%$. So, based on this percentage score it can be concluded that 29 students' mastery of learning material in the third cycle increased significantly.

\section{d. Reflection Stage}

This condition can be seen from an increase in student interest that is better than $71.88 \%$ in the second cycle to $78.80 \%$ in the third cycle. This can be seen in the changes in the observation results of lecturers' activities in learning using the recitation methods assisted by cyber counseling media from $83.77 \%$ in the second cycle to $87.77 \%$ in the third cycle. Changes in student learning interest in mastery of learning material were seen significantly based on data from the average score of the evaluation results of the two cycles, namely 74.40 in the second cycle with a success rate of $58.70 \%$ increasing in the third cycle to 85.83 with a success rate of $91.30 \%$.

In the pre-action stage the level of mastery of students was still very low with a percentage of graduation of only $23.91 \%$. During the first cycle, the recitation method was implemented and supported by the use of Cyber counseling media. At this stage the student graduation rate is $38.10 \%$. These results indicate that the level of learning interest is still relatively unsuccessful, but there has been an increase in the ability of students from the results of pre-action tests. In this action, student activities in the teaching and learning process are also still low with an average of $67.26 \%$. At the stage of action II the results of the test of students' ability to mastery the material increased compared to the first cycle with an average score of 74.40 with a graduation rate of $58.70 \%$. In addition, the activities of students and lecturers in PBM also improved with an average percentage of $71.88 \%$ and $83.77 \%$ respectively. The learning atmosphere has led to a recitation method better than the previous action, and is able to implement Cyber counseling as a more active learning media. The average score of students' ability to mastery of the material obtained in action III is 85.83 , with a graduation rate of $91.30 \%$. The average score of student activities in learning activities reached $78.80 \%$. Meanwhile, lecturers' activities in learning also improved well, with an average percentage of 87.77\%. This means that there was a significant increase in student interest and learning activities, and was declared very successful. 


\section{Conclusion}

Based on some of the results of the research described earlier, it can be concluded that the application of recitation methods assisted by Cyber Counseling media can significantly increase students learning interest, especially in Counseling Psychology learning.

\section{References}

Ahmadi, Abu. 2009. Psikologi Sosial. Jakarta: Rineka Cipta.

Amti, Erman and Prayitno. 2004. Layanan bimbingan dan konseling kelompok. Padang: Department of Guidance and Counseling, Faculty of Education, Padang State University Achmad, Nurdin.2011. Reaksi Analisa Protein .http://skp.unair.ac.id/repository/Guru Indonesia/Reaksi Analisa Protein Nurdin Achmad_57.pdf Accessed on friday, 31 October 2015

Dalyono 2009. Psikologi Pendidikan. Jakarta: Rineka Cipta.

Djaali 2006. Psikologi pendidika. Jakarta: Bumiaksara.

Moh. Surya, 2006. Bimbingan Dan penyuluhan Konseling di Sekolah Bandung: Rineka Cipta .Alfabeta.

M. Basyirudin Usman. 2002. Metodologi Pembelajaran Agama Islam. Jakarta Ciputat Pers. Majid Abdul. 2013. Strategi pembelajaran. Bandung. Remaja Rosdakarya Syaiful Sagala, 2005. Konsep dan Makna Pembelajaran Untuk Membantu Memecahkan Problematika Belajar dan Mengajar.

Syaiful Bahri Djamrah and Azwan Zain, 2010. Stretategi belajar Mengajar. Jakarta Renika cipta. 